\title{
Evaluation of the patients admitted to the pediatric cardiology department with chest pain: a single center experience
}

\author{
Göğüs ağrısı ile çocuk kardiyoloji bölümüne başvuran hastaların \\ değerlendirilmesi: Tek merkez deneyimi
}

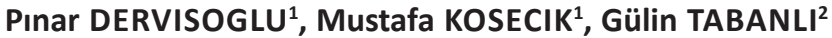

\section{ABSTRACT}

Chest pain is one of the most frequent causes of admissions into pediatric intensive care unit. In this study determination of the etiologies of the patients referred to our outpatient clinic with chest pain, detection of underlying cardiac causes, and questioning requirement for further diagnostic tests in children referred to our clinic with chest pain were aimed. We prospectively evaluated 248 children with chest pain who had had been referred to pediatric cardiology clinic of our hospital between November 2015, and February 2015. Detailed history forms were filled for each patient. All patients were evaluated with physical examination, electrocardiography, echocardiography, measurements of cardiac enzymes in case of need 24-hour Holter monitorization of cardiac rhythm The mean age of patients was $12.7 \pm 3.9$ years. In 235 cases (94.75\%), non-cardiac, and in 13 patients (5.24\%) cardiac pathologies were existent $v b$. Non-cardiac chest pain was detected in patients was related to idiopathic etiologies $(n=158$; $67.23 \%)$, costochondritis ( $n=49 ; 20.85 \%)$, overuse of muscles $(n=5 ; 2.12 \%)$, gastroesophageal reflux disease $(n=9 ; 3.82 \%)$, asthma ( $n=10$ patients; $4.25 \%)$, conversion ( $n=3 ; 1.27 \%)$, and gynecomastia ( $n=1 ; 0.42 \%)$. In the group with cardiac pathologies mitral valve prolapse ( $n=4 ; 1.6 \%)$, myopericarditis $(n=7 ; 2.8 \%)$ in 1 patient $(0.4 \%)$, supraventricular tachycardia $(n=1 ; 0.4 \%)$, and atrial septal defect $(n=1 ; 0.4 \%)$ were detected. Referral of the patients with acute onset pain unrelated to exercise and negative family history without associated dizziness or syncope and abnormal findings on physical examination and ECG to the clinics of paediatric cardiology for further testing will only cause anxiety, and high cost both for the patients and their families.
Öz

Göğüs ağrısı çocuk acile başvuruların en sık nedenlerinden biridir. Bu çalışmada polikliniğimize göğüs ağrısı ile yönlendirilen hastaların etiyolojilerinin belirlenmesi, altta yatan kardiyak nedenlerin saptanması ve gögüs ağrılı çocuklarda tanıya yaklaşımda yapılan ileri tetkiklerin gerekliliğinin sorgulanması amaçlanmıştır. Hastanemiz çocuk kardiyoloji polikliniğine Şubat 2015 ile Kasım 2015 tarihleri arasında gögüs ağrısı ile başvuran 248 hasta prospektif olarak değerlendirildi. Her hasta için ayrıntılı anemnez formları dolduruldu. Hastalar fizik muayene, elektrokardiogram, transtorasik ekokardiyografi ve gereken hastalarda kardiyak enzimler ve 24 saatlik ritm holter monitörizasyonu

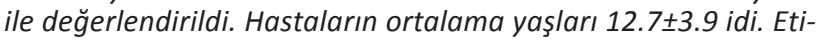
yolojide 235 olguda (\%94.75) non kardiyak, 13 olguda (\%5.24) kardiyak patoloji saptandı. Non kardiyak göğüs ağrıları içinde 158 olgu (\%67.23) idiopatik, 49 olgu (\%20.85) kostokondrit, 5 olgu (\%2.12) kasların aşırı kullanımı, 9 olgu (\%3.82) gastroözefageal reflü hastalı̆̆ı, 10 olgu (\%4.25) astım, 3 olgu (\%1.27) konversiyon, 1 olgu (\%0.42) jinekomasti olarak değerlendirldi. Kardiyak patoloji saptanan grupta, 4 hastada (\%1.6) mitral kapak prolapsusu, 7 hastada (\%2.8) myoperikardit, 1 hastada (\%0.4) supraventriküler taşikardi, 1 hastada (\%0.4) atriyal septal defekt görüldü. Akut başlangıçlı ve egzersizle ilişkili olmayan, senkop ya da baş dönmesinin eşlik etmediği, aile öyküsü negatif bulunan, fizik muayene ve EKG'sinde patolojik bulgu saptanmayan hastaların ekokardiyografi ve egzersiz testi gibi daha ileri tetkik amacıyla çocuk kardiyolojiye gönderilmesi hasta ve ailesinde gereksiz endişeye ve aşırı maliyete neden olmaktan öteye geçmeyecektir.

Anahtar kelimeler: Göğüs ağrısı, çocuk, kalp rağmen, çocuk kardiyoloji konsültasyonlarının önemli bir kısmını oluşturur ${ }^{1}$. Ebeveynlerin ciddi ölüm kaygıları nedeni ile bu hastalara gereksiz, uzun süreli ve maliyeti yüksek klinik değerlendirme yapılmaktadır. Bu çalışmada, polikliniğimize göğüs ağrısı ile yönlen-
Göğüs ağrısı çocuk acile başvuruların en sık nedenlerinden biridir. Erişkinlerin aksine kardiyak nedenli göğüs ağrıları çocuklarda oldukça ender olmasına

Received: 10.10 .2016

Accepted: 11.11 .2016

${ }^{1}$ Sakarya University Medical Faculty Department of Pediatric Cardiology

${ }^{2}$ Sakarya University Medical Faculty Department of Pediatrics

Yazışma adresi: Pınar Dervişoğlu, Sakarya University Medical Faculty Department of Pediatric Cardiology, Sakarya

e-mail: pdervisoglu@hotmail.com

This study was presented during the 15th National Pediatric Cardiology and Cardiac Surgery Congress, 13-16 April, 2016, Antalya, Turkey 
dirilen hastaların etiyolojilerinin belirlenmesi, altta yatan kardiyak nedenlerin saptanması ve göğüs ağrılı çocuklarda tanıya yaklaşımda yapılan ileri tetkiklerin gerekliliğinin sorgulanması amaçlanmıştır.

\section{GEREÇ ve YÖNTEM}

Hastanemiz çocuk kardiyoloji polikliniğine Şubat 2015 ile Kasım 2015 tarihleri arasında göğüs ağrısı ile başvuran 248 hasta prospektif olarak değerlendirildi. Çalışma için gerekli etik kurul onayı alındıktan sonra çalışmaya katılmayı kabul eden her hasta için ağrının şekli, ne kadar süredir hissedildiği, ne sıklıkta geldiği, ne kadar sürede sonlandığı, egzersizle ilişkisi, eşlik eden başka bir semptomun varlığı, yakın zamanda geçirilmiş enfeksiyon ve ailede genç yaşlarda ani ölüm öyküsü varlığı gibi soruları içeren ayrıntılı anemnez formları dolduruldu. Hastalar fizik muayene, elektrokardiogram, transtorasik ekokardiyografi ve gereken hastalarda kardiyak enzimler ve 24 saatlik ritm holter monitörizasyonu ile değerlendirildi. Tüm bunların sonucunda, tanı ve uygulanacak tedavi yöntemi belirlendi. Göğüs ağrılarını kategorize ederken, göğüs duvarında hassasiyetin olduğu, nefes almakla ilişkili, hareketle artan, kostokondral bölgede hassasiyetin eşlik ettiği ağrılar kas iskelet sistemine ait kabul edildi. Solunumsal kökenli olarak göğüs grafisinde akciğere ait patoloji saptanan veya wheezing, öksürük, astımın eşlik ettiği ağrılar kabul edilirken, yemekle ilişkili, midede yanma hissi, bulantı-kusmanın olduğu, ya da gastroskopi tanılı reflü, gastrit hastalağına sahip hastalardaki ağrılar gastrointestinal sistemle ilişkili ağrılar olarak kabul edildi. Emosyonel bozukluğu olan, altta yatan psikojenik yatkınlığın olduğu, okul ve aile problemleri yaşayan hastalardaki ağrılar psikojenik kökenli olarak kabul edildi. Altta yatan kalp hastalığı ya da ritim bozukluğu durum olan hastalar kardiyak kökenli olarak kabul edildi. Yapısal kalp hastalığı olan, laboratuvar bulguları, EKG ve göğüs grafisi normal olan hastalarda diğer nedenlerin yokluğunda ağrı kardiyak kökenli olarak kabul edildi. Yapısal kalp hastalığı olmayan, herhangi organik neden bulunamayan, diğer nedenlerin dışlandığı ağrılar ise idiopatik olarak kabul edildi.

\section{BULGULAR}

Çalışmaya alınan hastaların demografik özelliklerine bakıldığında, ortalama yaşları $12,7 \pm 3,9$ idi. Hastalar çoğunlukla 14 ile 16 yaş grupları arasındaydı. Yüz otuz ikisi $(\% 53,2)$ kız, 116'sı $(\% 46,8)$ erkekti. Hastalar 13,2 ile 87 kilo (ort 42.2) arasındaydı. Ailede 40 yaş öncesi ani ölüm tanımlayan iki olgu vardı (Tablo 1). Ağrının karakteristik özelliklerine bakıldığında, \%63 bıçak saplanır tarzda, \%12,4 nefes tutma şeklinde, $\% 7,8$ keskin, $\% 7,6$ basınç hissi, $\% 5,2$ künt ve $\% 3,8^{\prime}$ de yanıcı, kaşınma, çırpınma gibi çeşitli karakterlerdeydi. Kız ve erkek hastalar arasında ağrının karakteri açısından anlamlı bir farklılık yoktu (Tablo 2). Ağrının süresine bakıldığında non kardiyak göğüs ağrısı saptanan grupta ağrı, \%86,2 oranında 6 aydan fazla süredir varken, \%5,3 oranında 1 hafta ile 1 ay arasında, \%4,1 oranında 1 ile 6 ay arasında, \%3,2 oranında 2 ile 7 gün arasında, \%1,2 oranında ise 48 saatten az sürede ağrı tanımlıyordu. Kardiyak göğüs ağrısı olan grupta ise $\% 92,7$ oranında $2-7$ günden beri, $\% 7,6$ 'sı 48 saatten az süredir olan ağrı tanımlanmaktaydı (Tablo 3 ). Hastaların \%68'i haftada birden az, \%26'sı haftada bir kez, $\% 2,8$ 'i gün içinde birkaç kez, \%1,8'i hafta boyunca birkaç kez ve \%1,4'ü günde bir kereden az süreli ağrı tanımlamaktaydı. Ağrının sonlanması \%97,2 oranında saniyeler içinde olurken, \%2,4 dakikalar içinde, $\% 0,4$ ise saatler içinde sonlanmaktaydı. Hastaların

Tablo 1. Demografik özellikler.

Göğüs ağrısı ile başvuran hasta ( $n: 268)$

\begin{tabular}{ll}
\hline Kız n (\%) & $132(53,2)$ \\
Erkek n (\%) & $116(46,8)$ \\
Yaş (ortalama) yıl & $12,7(8,8-16,6)$ \\
Pozitif aile öyküsü n (\%) & $2(0,8)$
\end{tabular}

Tablo 2. Ağrının karakteri.

\begin{tabular}{lcllc}
\hline & \multicolumn{1}{c}{ kız } & erkek & toplam & p \\
\hline Bıçak saplanır n (\%) & $82(52,5)$ & $74(47,4)$ & $156(63)$ & 0,169 \\
Nefes tutma n (\%) & $15(48,3)$ & $16(51,7)$ & $31(12,4)$ & 0,251 \\
Keskin n (\%) & $11(57,8)$ & $8(42,1)$ & $19(7,8)$ & 0,090 \\
Basınç hissi n (\%) & $10(55,5)$ & $8(44,4)$ & $18(7,6)$ & 0,075 \\
Künt n (\%) & $6(46,1)$ & $7(53,8)$ & $13(5,2)$ & 0,187 \\
Diğer n (\%) & $5(45,4)$ & $6(54,5)$ & $11(4)$ & 0,832 \\
& & & & \\
\hline
\end{tabular}


\%3,6'sı yemekle ilişkili ağrı tanımlarken, \%19,7'si göğüse bastırmakla artan ağrı, \%4 öksürükle, \%2,8 derin nefes almakla ve $\% 2$ oranında ayakta durmakla artan ağrı tanımlamaktaydı. Ağrıya eşlik eden senkop, baş dönmesi, çarpıntı ve uykudan uyandıran göğüs ağrısı tanımlanmadı. Hastaların hiçbirinde egzersize eşlik eden ya da egzersiz öncesi ve sonrası ağrı yoktu. Kardiyak patoloji saptanan gurupta, 4 hastada $(\% 1,6)$ mitral kapak prolapsusu, 7 hastada $(\% 2,8)$ myoperikardit, 1 hastada $(\% 0,4)$ supraventriküler taşikardi, 1 hastada $(\% 0,4)$ atriyal septal defekte eşlik eden seyrek ventriküler erken atımların izlendiği benign aritmi görüldü (Tablo 4).

Tablo 3. Ağrının ne kadar süredir hissedildiği.

\begin{tabular}{lll}
\hline & n (hasta sayısı) & $\%$ \\
\hline 48 saatten az & 2 & 0,8 \\
2-7 gün arasında & 4 & 1,61 \\
1 hafta-1 ay arasında & 6 & 2,41 \\
1-6 ay arasında & 22 & 8,87 \\
6 aydan fazladır & 214 & 86,4 \\
\hline
\end{tabular}

Tablo 4. Etiyolojik nedenler.

\begin{tabular}{lll}
\hline & $\mathbf{n}$ & $\%$ \\
\hline Non kardiak & 235 & 94,75 \\
İdiopatik & 158 & 67,23 \\
Kostokondrit & 49 & 20,85 \\
Astım & 10 & 4,25 \\
GÖRH & 9 & 3,82 \\
Kasların aşırı kullanımı & 5 & 2,12 \\
Konversiyon & 3 & 1,27 \\
Jinekomasti & 1 & 0,42 \\
Kardiak & 13 & 5,24 \\
Myoperikardit & 7 & 2,8 \\
Mitral valve prolapsusu & 4 & 1,6 \\
Atrial septal defekt & 1 & 0,4 \\
Supraventriküler taşikardi & 1 & 0,4 \\
\end{tabular}

\section{TARTIŞMA}

Çocuklarda ve adolesanlarda görülen göğüs ağrıları erişkinlerin aksine selim seyretmesine rağmen, ailelerde yarattıkları endişe nedeniyle ciddi sosyal bir sorundur. Yıllardan beri geniş hasta grupları üzerinde göğüs ağrıları nedenleri uzun uzun araştırıımıştır. Hemen hepsinin ortak sonucu ağrıların sıklıkla non kardiyak kökenli olduğu lehinedir. Yakalaşık otuz yıl öncesinde Selbest M ve ark.'nın² 407 hasta üzerinde yaptıkları çalışmada, hastalar fizik muayene, laboratuvar bulguları, EKG ve eko ile değerlendirilmiş. Tüm nedenler arasında en sık \%21 oranında idiopatik grup saptanırken, kardiyak nedenler \%4 oranında bulunmuştur. Günümüzde fizik incelemeye yardımcı yöntemlerinin çok daha etkili kullanılabilmesine rağmen, sonuçlar benzer orandadır. Ji Hye Chun ve ark.'nın ${ }^{3}$ 2013 yılında 517 hasta üzerinde yaptıkları retrospektif çalışmada, \%73,6 oranında idiopatik, \%3,8 oranında kardiyak nedenler saptanmış. Thull-Freedman J'nin 2010 yılında yayınlanan 3700 vakalık geniş kohort çaısşmasında, göğüs ağrısı ile başvuran hastaların fizik muayeneleri ve EKG kayıtları incelenmiş, en geniş vakaya sahip olan bu çalışmada, egzersizle birlikte ağrı \%33 oranında bulunmuştur. Palpitasyon \%22, dispne $\% 16$, baş dönmesi $\% 11$, senkop $\% 1,3$ oranında bulunmuştur. Hastaların yalnızca \%38'ine EKO yapılmış ve $\% 0,8$ 'inde kardiyak patoloji ile ilişkili göğüs ağrısı bulunmuştur. Palpitasyonu olan tüm hastaların 24 saatlik holter kayıtları incelenmiş ve yalnızca \%0,4'ü pozitif olarak değerlendirilmiştir ${ }^{4}$. Çalışmamızda, egzersizin, palpitasyonun ya da senkopun eşlik ettiği hiçbir hasta yoktu. Supraventriküler taşikardi saptanan bir hastamız vardı ve yalnızca göğüs ağrısından yakınmaktaydı. Non kardiyak ağrılar $\% 94,75$ oranındaydı ve bunların arasında $\% 67,23$ oranındaki en büyük payı idiopatik grup oluşturmaktaydı. \%20,85 oranında kostokondrit ikinci en sık neden iken, sırasıyla \%4,25 oranında astım ve \%3,82 oranında da reflü saptandı. Bu haliyle çalışmamız diğer çalışmalarla benzer nitelikteydi ${ }^{5-8}$. Biz yapısal kardiyak defektleri taramak amacıyla tüm hastalarımızı eko ile değerlendirdik. Dört hastada MVP vardı ve papiller kasların gerilmesine bağlı lokal ağrı olabileceğinden kardiyak kökenli ağrı olarak kabul ettik, bir hastada ASD saptadık. Aynı hastada seyrek ventriküler erken atımlar olması nedeniyle de kariyak ağrı olarak değerlendirdik. Kronik olan, öyküsünde ve fizik muayenesinde özellik bulunmayan hastalardaki göğüs ağrıları genelde organik nedene bağlı olmayan ağrılardır. Ağrı başladıktan sonraki 48 saat içinde hastaneye başvuran hastalarda sıklıkla organik bir neden bulunur. Sert A ve ark.'nın ${ }^{9} 380$ vakalık prospektif çalışmalarında, tüm hastaların \%7 ile 
$45^{\prime}$ i 6 aydan uzun süren kronik ağrı ile başvurmuş. \%1 oranında hastalarda 1 yılı aşkın süredir göğüs ağrısı olduğu saptanmıştır. Kardiyak nedenli göğüs ağrısı $\% 0,3$ oranında bulunmuş. Diğer çalışmalara kıyasla daha düşük saptanan bu oranı insidental saptadıkları MVP'yi kardiyak kökenli ağrı grubuna katmamaları olarak yorumlamaktadırlar. Çalışmamızda non kardiyak kökenli ağrıların \%86,2'si 6 aydan fazla süredir ağrı tanımlarken yalnızca \%1,2'si 48 saatten az süreli göğüs ağrısı ile başvurmuştu. Kardiyak kökenli ağrısı olan hastaların $\% 7,6^{\prime}$ sı 48 saatten az, geri kalanları ise ilk bir hafta içinde başlayan ağrı ile hastaneye başvurmuştu. Ağrının süresine bakıldığında hastaların $\% 97,2$ oranındaki büyük çoğunluğunda ağrı saniyeler içinde sonlanırken yalnızca SVT ile gelen bir hastamızda ağrı saatler içinde sonlanmıştı.

Thomas Perry ve ark.'nın ${ }^{10} 1997$ vakalık bir grup hasta üzerinde yaptıkları çalışmada, senkop, palpitasyon ve ağrının 2 ile 7 gün içinde başlamış olması minör kardiyak hastalıklar ile ilişkilendirilirken, egzersizin eşlik ettiği göğüs ağrısı kardiyak hastalık arasında ilişki bulunamamıştır. Bu haliyle birçok çalışma ile ayrı düşmüştür. Biz de çalışmamızda, egzersizin eşlik ettiği bir ağrıya rastalamadık. Ancak vaka sayımızın diğer çalışmalara kıyasla az olduğu ve egzersizin tetikleyeceği ciddi kardiyak defektlerin görülme sıklığı göz önüne alındığında literatürle uyumlu olduğu söylenebilir.

\section{SONUÇ}

Çocuklarda kardiyak nedenli göğüs ağrıları ender görülür. Dikkatle detaylı alınmış bir öykü ile desteklenen fizik muayene ve EKG'sinde anormal bulgusu olmayan hastalarda kardiyak nedenler büyük olasılıkla dış- lanabilmektedir. Dolayısıyla kardiyak düşünülmeyen göğüs ağrılarının, daha ileri tetkik amacıyla çocuk kardiyolojisine yönlendirilmesi hasta ve ailesinde gereksiz endişeye neden olmaktan öteye geçmemektedir. Bu nedenle, akut başlangıçlı, egzersizle ilişkili, senkop ya da baş dönmesinin eşlik ettiği, aile öyküsü pozitif, fizik muayene ya da EKG de patoloji saptanan hastaların çocuk kardiyoloji bölümüne yönlendirilmesinin uygun olacağı düşüncesindeyiz.

\section{KAYNAKLAR}

1. Park MK. Chest pain. In: Myung K. Park (eds.), Park's Pediatric Cardiology for Practitioners. $6^{\text {st }}$ ed. Philadelphia USA, Saunders, Inc; 2014. p.38-40.

2. Selbest MS, Ruddy RM, Clark BJ, Frederick MH, Santulli T. Pediatric chest pain:prospective study. Pediatrics 1988;82:319-323.

3. Chun JH, Kim TY, Han Y, Kim NY et al. Analysis of clinical characteristics and causes of chest pain in children and adolescents. Korean J Pediatr 2015;58:440-445. https://doi.org/10.3345/kjp.2015.58.11.440

4. Thull-Freedman J. Evaluation of chest pain in the pediatric patient. Med Clin North Am 2010;94:327-47. https://doi.org/10.1016/j.mcna.2010.01.004

5. Shin SA, Kim YJ, Lee JW, Kim NS et al. Clinical evaluation and diagnosis of children with chest pain. J Korean Pediatr Soc 2003;46:1248-52.

6. Cava JR, Sayger PL. Chest pain in children and adolescents. Pediatr Clin North Am 2004;51:1553-68. https://doi.org/10.1016/j.pcl.2004.07.002

7. Danduran MJ, Earing MG, Sheridan DC, Ewalt LA et al. Chest pain: characteristics of children/adolescents. Pediatr Cardiol 2008;29:775-81.

https://doi.org/10.1007/s00246-008-9200-9

8. Leung AK, Giuffre RM. Pediatric chest pain. Clin Pediatr (Phila) $2004 ; 43: 863$. https://doi.org/10.1177/000992280404300914

9. Sert A, Aypar E, Odabaş D, Gölçen C. Clinical charecteristics and causes of chest pain in 380 children referred to a pediatric cardiology unit. Cardiology in the Young 2013;23:361-367. https://doi.org/10.1017/S1047951112000881

10. Perry $\mathrm{T}$, Zha H, Oster ME, Frias PA et al. Utility of a clinical support tool for outpatient evaluation of pediatric chest pain. AMIA Annu Symp Proc 2012;2012:726-33. 